\title{
Reproductive biology of the hermit crab Pagurus nigrofascia (Anomura: Paguridae)
}

\author{
Seiji Goshima, Satoshi Wada, and Hirofumi Ohmori
}

Abstract. - The distribution and reproductive biology of the hermit crab Pagurus nigrofascia Komai, 1996, were studied from March 1992 to May 1995 at Kattoshi, Hakodate Bay, northern Japan. The species was distributed in the upper intertidal zone, mainly at pebble-covered areas on the shoreline. Ovigerous females were observed from April to February. Developmental stages of incubated eggs were synchronized within the population. The appearance of ovigerous females and examination of developmental stages of eggs revealed that the main spawning month was May, females oviposited once a year, and eggs were incubated for about nine months through the hot summer and cold winter. This long incubation period is a striking reproductive characteristic compared with other Pagurus spp., and suggests a wide variety of reproductive features may exist within the same genus Pagurus, even among species living in the same habitat.

\section{Introduction}

In northern Japan, there are several abundant hermit crab species belonging to the genus Pagurus (Paguridae), in subtidal and intertidal zones (Miyake, 1982; Komai et al., 1992). Pagurus nigrofascia, described by Komai (1996), is commonly seen near the shoreline around Hakodate Bay, southern Hokkaido, Japan. It is one of the four most common species of Pagurus in the rocky tidal flat at Kattoshi, located at the southwest side of the bay.

Usually, there is a considerable time lag between the morphological description of new species and subsequent reports on its biology and ecology, which may cause insufficient understanding of the species. Further, ecological information such as the distribution, reproduction, and life history of the genus Pagurus is still scarce, even for the common intertidal-dwelling hermit crabs (e.g., Imazu \& Asakura, 1994; Wada et al., 1995; Ohmori et al., 1995; Goshima et al., in preparation). Thus, we need more ecological information to understand this common genus.

In this paper, we describe the distribution along a rocky tidal flat and the reproductive biology of $P$. nigrofascia near the type-locality, Kattoshi, Hakodate Bay. In addition, we compare the reproductive characteristics of $P$. nigrofascia with those of other Pagurus species.

\section{Materials and Methods}

Sampling and observations of the hermit crab were done on a flat intertidal rocky shore at Kattoshi, located along the southwest side of Hakodate Bay, southern Hokkaido, Japan $\left(41^{\circ} 44^{\prime} \mathrm{N}, 140^{\circ} 36^{\prime} \mathrm{E}\right)$. The slope of the rocky flat is gentle and covered by many scattered cobbles. A detailed description of the study area is given by Nagata (1983)

We conducted line-transect sampling in April 1994 to clarify the species specific distribution pattern of hermit crabs on the tidal flat. Five lines perpendicular to the shoreline were set on the flat at $10 \mathrm{~m}$ intervals, and five $25 \times 25 \mathrm{~cm}$ quadrats were placed $0,50,100,150$, and $200 \mathrm{~m}$ from the shoreline on each line. All hermit 
crabs within each quadrat were collected, identified and counted.

Monthly sampling was carried out from March 1992 to March 1993 during low tides by turning over cobbles near the shoreline, where $P$. nigrofascia is mainly distributed. All P. nigrofascia collected were sexed based on the absence (male) or presence (female) of the first pleopod. The shield length (calcified anterior portion of the cephalothorax; hereafter, SL) of each specimen was measured to the nearest 0.1 $\mathrm{mm}$.

To determine the size at first maturity of females, the percentage of ovigerous females for various size classes was examined during June to January, when a high percentage of ovigerous females was observed. Both ovigerous and non-ovigerous females were pooled separately during this period due to the small sample size, although such pooling might cause a bias toward the non-ovigerous females because some matured females might be non-ovigerous and grow through molting during the period. Just spawned females were collected in May 1995, and the number of eggs were counted under a binocular microscope to estimate the relationship between female size and number of eggs.

To determine the incubation period and the development of eggs incubated by females for $P$. nigrofascia, all females larger than $4 \mathrm{~mm}$ SL were classified into three types: non-ovigerous (NO), ovigerous (OV), and post-ovigerous (POV), which had only egg capsules on the pleopods. Egg capsules were observed for several days after the eggs hatched. Eggs incubated by females were further classed into one of five developmental stages defined by Wada et al. (1995). Stage A eggs are newly deposited and completely filled with yolk. Stage B eggs have more than $80 \%$ of original yolk volume. This stage was not observed in the present study due, probably, to the rapid

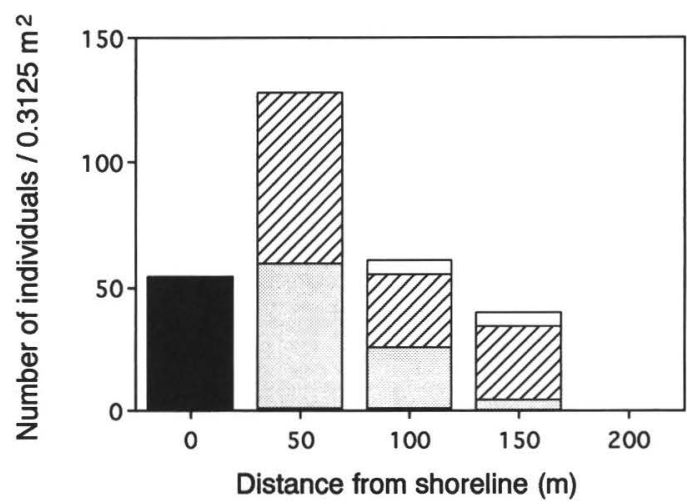

\section{Pagurus nigrofascia $\square$ Pagurus middendorffii Pagurus filholi Others}

Fig. 1. Distribution of the hermit crabs on the intertidal rocky flat at Kattoshi, Hakodate Bay, Hokkaido in April 1994. Pagurus nigrofascia was mainly distributed at the shoreline. Other species included Pagurus lanuginosus and Paguristes ortmanni.

sequence of stages relative to the sampling intervals. In stage $\mathrm{C}$ eggs, the yolk is reduced to $50-80 \%$ of the original volume, and no eye pigment is visible. Stage D eggs have less than $50 \%$ of the original yolk volume, and the eye pigment is present, but the eye shape is incomplete. Stage E eggs have a colorless embryo with well-developed oval eyes visible, and their yolk is reduced to less than $20 \%$ of the original volume. P. nigrofascia females spawn once a year and their egg development is very synchronous (a more detailed explanation will be appeared in the Results). This allowed us to estimate the duration of the successive egg developmental stages and the mean incubating period of females.

During April and May, males were often observed grasping edge of shells occupied by ripe females. This is a precopulatory female-guarding behavior displayed by males during the reproductive season. We captured 14 pairs in April and May 1992, measured the SL of both sexes, and observed their behavior in an aquarium. 


\section{Results}

Distribution of the hermit crabs on the tidal flat

Figure 1 shows the distribution of her-
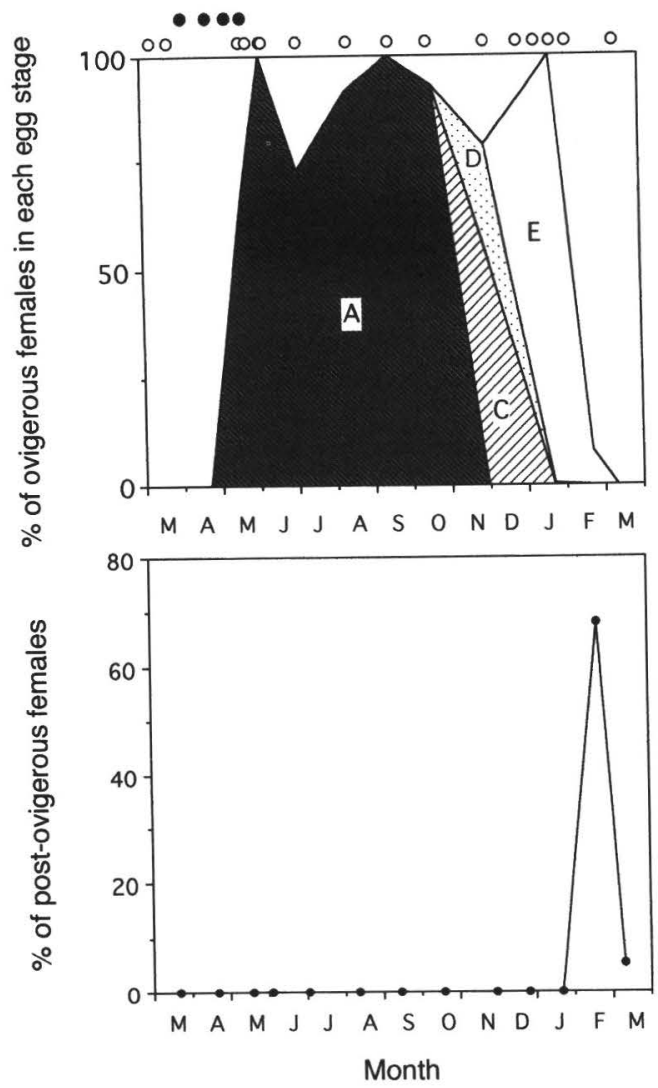

Fig. 2. Reproductive season of Pagurus nigrofascia. Upper: developmental stages of the eggs incubated by females. Egg stage A: completely filled with yolk with no clear space; B: yolk free portion visible and yolk volume more than $80 \%$ of original volume (this stage was not observed in the present study probably due to rapid sequence of the stage); C: yolk reduced to $50-80 \%$ and no eye pigment visible; D: yolk reduced to less than $50 \%$ and incomplete shape of pigmented eye visible; $\mathrm{E}$ : oval eye in shape and yolk reduced to less than $20 \%$ (see text for more detailed explanation). Closed and open circles indicate the days when precopulatory guarding behavior was seen and not seen, respectively. Lower: monthly changes in the percentage of post-ovigerous females which had only egg capsules on the pleopods just after hatching. mit crabs on the Kattoshi rocky intertidal flat in April 1994. Five species of hermit crabs were found in the quadrats: Pagurus middendorffi, $P$. filholi, $P$. nigrofascia, $P$. lanuginosus, and Paguristes ortmanni, the first three species were most common. $P$. nigrofascia was mainly distributed at the shoreline $(0 \mathrm{~m})$. A few crabs were also observed at 50 and $100 \mathrm{~m}$ points from the shoreline.

Mating, spawning and incubation of eggs

Precopulatory guarding behavior by males was often observed in April and May (Fig. 2, upper). In 14 pairs observed in the field, the guarding males were always larger (SL range $=4.8-7.8 \mathrm{~mm}$ ) than their female partners $(3.0-5.7 \mathrm{~mm})$. In the aquarium observations, the pairs copulated, the female oviposited eggs on her pleopods, and the guarding behavior ended when spawning was completed. The average guarding period after capture was $2.6 \pm 0.8 \mathrm{SD}$ days (range $=1-4$ days, $n=14$ ) in the tank, and thus the guarding behavior probably lasted for up to 4 or 5 days in the field.

OV females first appeared in April 1992 (Fig. 2, upper). The percent of OV females increased abruptly to $100 \%$ of all females in June, with the spawning peak occurring in May. The frequency of OV females remained high from June to January. Stage A eggs dominated from May to October. Stage C eggs were seen in November, followed by stage $D$ eggs from November to December, and stage E eggs in January and February. The percentage of OV females decreased from January to March, with the peak of larvae release occurring in February. No OV females were observed in March. No POV females were observed from March 1992 to January 1993. The percent of POV females increased in February, followed by a drop in March 1993 (Fig. 2, lower).

The increase in the percentage of $\mathrm{OV}$ females to nearly $100 \%$ and the strong synchrony of egg development indicate fe- 
males spawn only once a year. The duration of each egg stage was estimated to be $180,26,20$, and 43 days, respectively; the total incubation duration was calculated to be 269 days. During the incubation period, the highest semi-monthly mean water temperature was $24.8^{\circ} \mathrm{C}$ in the first half of August, and the lowest was $3.2^{\circ} \mathrm{C}$ in the first half of February.

The size at sexual maturity is shown in Fig. 3, in which the percentage of OV female is represented for each size class. The minimum SL of OV females was 2.8 $\mathrm{mm}$. Fifty-three percent of the females in the 3.4-3.6 $\mathrm{mm}$ class spawned. This rate increased to $96 \%$ for females larger than 4 $\mathrm{mm}$. The $4.8-5.0 \mathrm{~mm}$ class had a slightly lower rate $(73 \%)$ due, probably, to the small sample size. The 50\% sexual maturity size (SM 50), defined as the size at which half of the females spawned, was $3.5 \mathrm{~mm}$.

Figure 4 shows the relationship between SL $(\mathrm{mm})$ and brood size (E, number of eggs spawned) for the females sampled in May 1995, just after spawning. The number of eggs increased with SL, ranging from 151 eggs at $3.1 \mathrm{~mm}$ SL to 325 eggs at $4.2 \mathrm{~mm}$ SL. The regression line is represented as $\mathrm{E}=86.1 \mathrm{SL}-77.2(\mathrm{n}=20$, $\left.\mathrm{r}^{2}=0.262, P<0.05\right)$.

\section{Discussion}

$P$. nigrofascia was mainly distributed at the shoreline (Fig. 1), and the same distribution pattern was observed throughout the year (Ohmori et al., unpublished data). These findings indicate there may be no seasonal or size-dependent migration for this hermit crab. A similar pattern of no migration was also observed for the other pagurid species in Hakodate Bay (Ohmori et al., unpublished data).

Mate-guarding behavior of ripe females by males is known for several pagurid hermit crabs and lithodid crabs among Anomura (e.g., Imafuku, 1986; Goshima, 1994; Imafuku \& Ikeda, 1995;

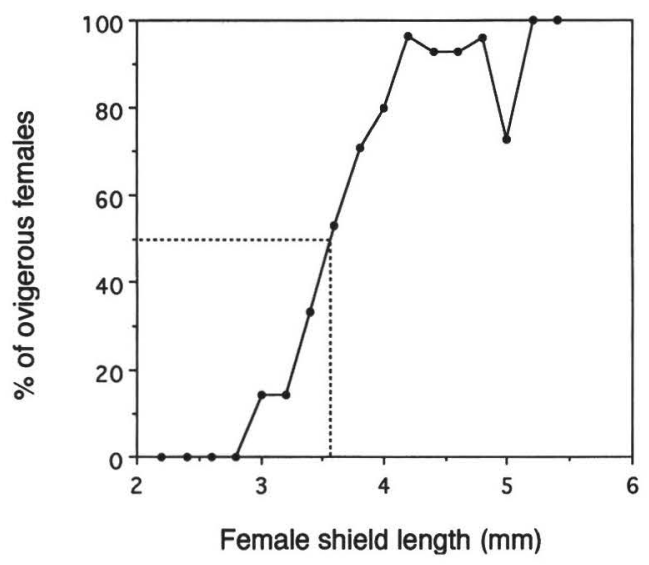

Fig. 3. Percentage of Pagurus nigrofascia females that were ovigerous as a function of shield length, sampled during June to January $(n=523)$. Broken line indicates the shield length corresponding to the $50 \%$ maturity level (SM 50).

Goshima et al., 1995; Wada et al., 1995; Goshima et al., in preparation). Such guarding behavior is commonly observed in all four pagurid species inhabiting Kattoshi (Wada et al., 1995; Goshima et $a l$., unpublished data), and probably occurs in many other pagurid species. Mateguarding behavior might help males retain ripe females from other competitive males (Goshima et al., 1995; Goshima et al., 1996). Anomura, such as the red king crab and the hermit crabs, have no copulatory appendages, and fertilization occurs externally just after copulation (Marukawa, 1933; Goshima et al., 1995). Therefore, the last mating male has an advantage since his sperm will most likely be used for fertilization. The precopulatory guarding might be often seen in species with a restricted copulation period (Yamamura, 1987). Male hermit crabs may ensure their paternity by securing their mates from other males until the female can copulate and spawn (Goshima et al., 1995).

The estimated incubation period of about nine months for $P$. nigrofascia is 


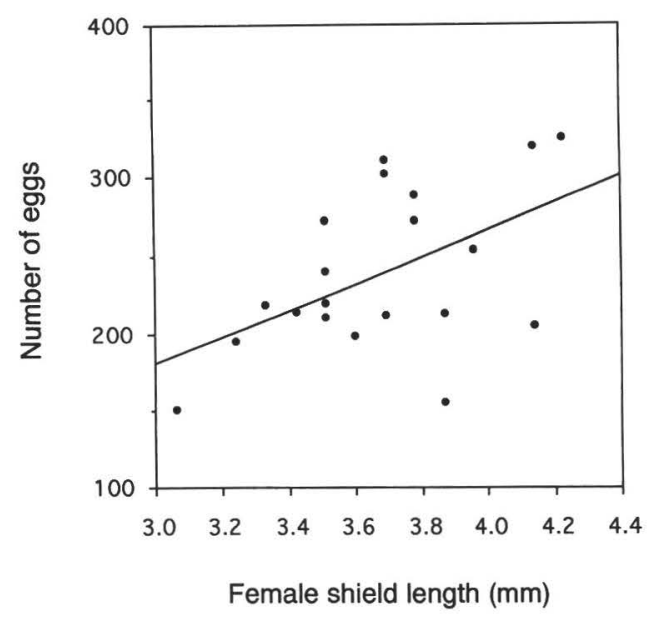

Fig. 4. Regression line of egg numbers versus shield length of female Pagurus nigrofascia sampled in May 1995 just after spawning. The line is described by $\mathrm{E}=86.1 \mathrm{SL}-77.2(\mathrm{n}=20, \mathrm{r}$ $=0.512, P<0.05$ ), where $\mathrm{E}$ is number of eggs and SL is shield length ( $\mathrm{mm})$.

much longer than those of any other hermit crabs, even those within the same genus Pagurus (e.g., two weeks for Clibanarius albidigitus (Bertness, 1981); two to three weeks for Diogenes nitidimanus (Asakura, 1987); three months for Pagurus bernhardus (Pike \& Williamson, 1959); three and a half months for $P$. middendorffii (Wada et al., 1995); 16 days or more for $P$. filholi (Goshima et al., in preparation)). Incubation periods probably depend on temperature. Indeed, lithodine crabs, such as the king crabs Paralithodes camtschatica, $P$. brevipes, and $P$. platypus, incubate their eggs for about one year or more (e.g., Marukawa, 1933; Sato \& Abe, 1941; Sasakawa, 1973; Matsuura \& Takeshita, 1976; Somerton \& MacIntosh, 1985; Shirley et al., 1989). These crabs inhabit deep waters where temperatures are low and relatively constant (Dawson \& Yaldwyn, 1985; Shirley et al., 1989). $P$. nigrofascia, on the other hand, inhabit the shallower intertidal zone, where amplitude of temperature fluctuation is large throughout the year. Incubated eggs experience temperatures ranging from 25 ${ }^{\circ} \mathrm{C}$ in summer to $3{ }^{\circ} \mathrm{C}$ in winter. Further, the latter two pagurid hermit crabs described above ( $P$. middendorffii and $P$. filholi) inhabit the same intertidal flat as the present species, and thus experience the same environmental conditions, such as temperature and salinity. However, these species show considerable difference in the period of egg incubation. Thus, a factor other than temperature appears to be responsible for the longer incubation period observed in $P$. nigrofascia.

The developmental pattern of incubated eggs is also a striking reproductive feature. Eggs that completely filled with yolk and no clear space visible (stage A, typical just after oviposition) were observed for a considerably long period; for six months out of nine months of the total incubation period (Fig. 2). Thus, at least externally, it is possible no egg development occurs during this period. Indeed, the eggs looked like they were just oviposited during the long period. Relatively rapid egg development was observed in later period until hatching in February (Fig. 2). In contrast, Wada et al. (1995) have reported egg development of $P$. middendorffii in the same habitat is relatively constant. The adaptive meaning of this long incubation period and the mechanisms that control the development of eggs are unknown.

The genus Pagurus may include more than 100 species; 31 species from Japan (Miyake, 1982), 25 species from northwestern North America (McLaughlin, 1974), and more than 50 pagurid species from other areas have been described (Alcock, 1905; Forest, 1966; Forest \& Laurent, 1967; Williams, 1984; Ingle, 1993). It is one of the most species-rich genera in Anomura, which are mainly distributed worldwide in shallow waters, such as littoral, subtidal and intertidal areas. Their reproductive characteristics vary widely, even among the species inhabiting the same habitat, as shown in 
this study. Furthermore, a single species inhabiting different localities may have different reproductive schedules; e.g., $P$. bernhardus in Elwood \& Neil (1992); $P$. filholi appeared in Imafuku (1986), Imazu \& Asakura (1994), and Goshima et $a l$. (in preparation). The highly diverse and plastic reproductive characteristics may provide a good opportunity to study the fitness consequences of different reproductive strategies. The ecological information for Pagurus is, however, still scarce despite the easily accessible habitats it inhabits and its high abundance. Such information should be clarified in further studies.

\section{Acknowledgments}

We thank T. Komai, R. W. Elwood, and M. Imafuku for their helpful comments on the manuscript.

\section{Literature Cited}

Alcock, A., 1905. Anomura. Fasc. I. Pagurides. Catalogue of the Indian decapod Crustacea in the collection of the Indian Museum, 2: 1-197. Indian Museum, Calcatta.

Asakura, A., 1987. Population ecology of the sand-dwelling hermit crab Diogenes nitidimanus Terao: 3. Mating system. Bulletin of Marine Science, 41: 282-288.

Bertness, M. D., 1981. Seasonality in tropical hermit crab reproduction in the Bay of Panama. Bulletin of Marine Science, 13: 292-300.

Dawson, E. W., \& Yaldwyn, J. C., 1985. King crabs of the world or the world of king crabs: an overview of identity and distribution - with illustrated diagnostic keys to the genera of the Lithodidae and to the species of Lithodes. Proceedings of the International King Crab Symposium, Anchorage, Alaska, 69-106.

Elwood, R. W., \& Neil, S. J., 1992. Assessments and decisions. A study of information gathering by hermit crabs. Chapman \& Hall, London. pp. 192.

Forest, J., 1966. Campagne de la Calypso dans le golfe de Guinee et aux iles Principe, Sao Tome et Annobon (1956), 17. Crustaces Decapodes: Pagurides. Annales de I'Institut Oceanographique, 44: 125-172.

Forest, J., \& Laurent, M. de Saint, 1967.
Campagne de la Calypso au large des cotes Atlantique de sud (1961-1962), 1: 6, Crustaces Decapodes: Pagurides. In Resultats Scientifiques des Campagnes de la "Calypso". Annales de I'Institut Oceanographique, 45: 47-169, pl. 1.

Goshima, S., 1994. Crustacea in coastal region in southern Hokkaido. pp. 47-55. In: Committee of Network for Natural History of Southern Hokkaido, (ed.), Natural History of Southern Hokkaido. 182 pp., Genyosha, Hakodate. (In Japanese)

—, S., Ito, K., Wada, S., Shimizu, M., \& Nakao, S., 1995. Reproductive biology of the stone crab Hapalogaster dentata (Anomura: Lithodidae). Crustacean Research, 24: 8-18.

—, S., Koga, T., \& Murai, M., 1996. Mate acceptance and guarding by male fiddler crabs Uca tetragonon. Journal of Experimental Marine Biology and Ecology, 196: 131-143.

Imafuku, M., 1986. Sexual discrimination in the hermit crab Pagurus geminus. Journal of Ethology, 4: 39-47.

- M., \& Ikeda, H., 1995. On two types of the hermit crab Pagurus lanuginosus (Crustacea: Anomura: Paguridae). Publication from the Seto Marine Biological Laboratory, Kyoto University, 36: 339349.

Imazu, M., \& Asakura, A., 1994. Distribution, reproduction and shell utilization patterns in three species of intertidal hermit crabs on rocky shore on the Pacific coast of Japan. Journal of Experimental Marine Biology and Ecology, 184: 41-65.

Ingle, R., 1993. Hermit crabs of the northeastern Atlantic Ocean and Mediterranean Sea. pp. 1-495. Natural History Museum Publication, London.

Komai, T., Maruyama, S., \& Konishi, K., 1992. A list of decapod crustaceans from Hokkaido, northern Japan. Researches on Crustacea, 21: 189-205.

- T., 1996. A new intertidal species of Pagurus (Decapoda: Anomura: Paguridae) from Japan. Crustacean Research, 25: 5972.

Marukawa, H., 1933. Biological and fishery research on Japanese king-crab Paralithodes camtschatica (Tilesius). Journal of the Imperial Fisheries Experimental Station, Tokyo, 4: 1-152, 19 pls. (In Japanese with English abstract)

Matsuura, S., \& Takeshita, K., 1976. Molting and growth of the laboratory-reared king crab, Paralithodes camtschatica (Tilesius). 
Report of Fishery Research Laboratory, Kyushu University, 3: 1-14.

McLaughlin, P. A., 1974. The hermit crabs (Crustacea, Decapoda, Paguridae) of northwestern North America. Zoologische Verhandelingen, 130: 1-396.

Miyake, S., 1982. Japanese Crustacean Decapods and Stomatopods in Color. Vol. 1. Macrura, Anomura and Stomatopoda. Hoikusha, Osaka. vii + 261 pp., 56 pls. (In Japanese)

Nagata, M., 1983. Bioenergetics of the benthic herbivorous populations in a rocky intertidal habitat. Bulletin of the Japanese Society of Scientific Fisheries, 49: 33-40.

Ohmori, H., Wada, S., Goshima, S., \& Nakao, S., 1995. Effects of body size and shell availability on the shell utilization pattern of the hermit crab Pagurus filholi (Anomura: Paguridae). Crustacean Research, 24, 85-92.

Pike, R. B., \& Williamson, D. I., 1959. Observations on the distribution and breeding of British hermit crabs and stone crab (Crustacea: Diogenidae, Paguridae and Lithodidae). Proceedings of Zoological Society of London, 132: 551-567.

Sasakawa, Y., 1973. Studies on blue king crab resources in the western Bering Sea - I. Spawning cycle. Bulletin of the Japanese Society of Scientific Fisheries, 39: 10311037. (In Japanese with English summary)

Sato, S., \& Abe, Y., 1941. Number of eggs spawned by Paralithodes brevipes. Monthly Journal of Hokkaido Fisheries
Experimental Station, 481: 244-246. (In Japanese)

Shirley, T. C., Shirley, S. M., \& Korn, S., 1989. Incubation period, molting and growth of female red king crabs: effects of temperature. Proceedings of the International Symposium on King and Tanner Crabs, Anchorage, Alaska, 51-63.

Somerton, D. A., \& MacIntosh, R. A., 1985. Reproductive biology of the female blue king crab Paralithodes platypus near the Pribilof Islands, Alaska. Journal of Crustacean Biology, 5: 365-376.

Wada, S., Goshima, S., \& Nakao, S., 1995. Reproductive biology of the hermit crab Pagurus middendorffii (Anomura: Paguridae). Crustacean Research, 24: 2332.

Williams, A. B., 1984. Shrimps, lobsters, and crabs of the Atlantic coast of the eastern United States, Maine to Florida. pp. ixviii, 1-550. Smithsonian Institution, Washington, D.C.

Yamamura, N., 1987. A model on correlation between precopulatory guarding and short receptivity to copulation. Journal of theoretical Biology, 127: 171-180.

Address: Faculty of Fisheries, Hokkaido University, 3-1-1 Minato, Hakodate 041, Japan.

E-mails: (SG) goshima@fish.hokudai.ac.jp; (SW) swada@fish.hokudai.ac.jp 